\title{
O Advogado e a Realidade do Direito Penal*.
}

\author{
Manoel Pedro Pimentel \\ Professor Titular de Direito Penal na \\ Faculdade de Direito da Universidade de \\ São Paulo
}

Aqui compareci, hoje, atendendo a um honroso convite do Dr. Cid Vieira de Souza, ilustre Presidente da Secção de São Paulo da Ordem dos Advogados do Brasil, a fim de presidir à sessão de abertura do I Encontro dos Advogados Criminais do Estado de São Paulo. Estava, portanto, inteiramente despreparado para desempenhar a tarefa, que me foi cometida há poucos momentos, de substituir o conferencista, D. Serrano Neves, que não pôde comparecer por motivo de última hora.

Advogado criminal que sou, entendi não poder recusar a convocação, exatamente porque o improviso é um apanágio do criminalista. Peço, entretanto, dupla desculpa. Em primeiro lugar, porque os participantes deste encontro ficarão privados de ouvir o brilhante orador que estava programado e, em segundo lugar, porque deverão aturar um improviso, no mais amplo sentido da palavra, pois não tive tempo nem mesmo para esboçar um roteiro da conferência que irei pronunciar.

Se, quando iniciei minha vida profissional, alguém pretendesse realizar um Encontro de Advogados Criminais no salão nobre da Faculdade de Direito de São Paulo, e afirmasse que estariam presentes mais de vinte pessoas, seria tomado por louco. No entanto, passados apenas 30 anos, estamos assistindo a esta esplêndida realidade, e constatando que o certame conseguiu lotar, praticamente, o salão.

Embora a advocacia criminal ainda seja considerada o ramo menos favorecido das atividades do bacharel em Direito,

* Conferência proferida na abertura do I. ${ }^{\circ}$ Encontro dos Advogados Criminais, realizado na Faculdade de Direito da Universidade de São Paulo, em 8 de dezembro de 1977. 
pois não oferece atração remuneratória, a verdade é que não existe outro setor em que se encontrem tantos motivos de gratificação pessoal para o advogado.

Sempre ouvi dos meus alunos, quando lhes indagava, no início de cada ano letivo, a respeito das suas preferências profissionais, a afirmativa de que sentiam grande atração pelo Direito Penal, sobretudo pelo seu manifesto lado humano, mas que infelizmente não se poderiam dedicar à advocacia criminal, porque não era compensadora, quanto aos honorários.

Esta colocação nos permite concluir que, na verdade, a advocacia criminal exige, para o seu exercício, uma grande dose de desprendimento e de paixão. Sem essa paixão, sobretudo, não há advogado criminal. A identificação com o cliente e com a causa passa a ser uma verdadeira necessidade, como que uma transferência, reclamando que o advogado viva efetivamente o drama judiciário de que participa, não como um objetivo manipulador, mas como um autêntico protagonista.

$\mathrm{O}$ advogado criminal que se limitar ao patrocínio da causa, conduzindo-se, embora, com exação e inteligência, não se completará jamais. Somente aquele que se dá por inteiro, colocando também o coração a serviço da causa, é que chegará a ser um verdadeiro advogado criminal. Lembro-me da expressiva brincadeira que um velho criminalista repetia ao fim de cada ano: "Neste ano pratiquei quinze homicídios, doze estelionatos, três peculatos, etc.", descrevendo os casos que patrocinara e com os quais se identificara de tal forma que lhe parecia ter, realmente, assumido a autoria dos delitos.

Se não for esta a disposição do criminalista, certamente não chegará à meta efetivamente desejada. E talvez seja uma explicação para o fato de tão poucos escolherem este ramo da advocacia. Quantos encontraram abreviados seus dias de vida, por se manterem fiéis ao destino de servir sem reservas. $\mathrm{E}$, quantos outros, mal granjeada a fama, que é mais facilmente conseguida pelo criminalista, praticamente abandonam o campo, voltando-se para outras atividades mais rendosas, menos exigentes e menos cansativas, poupando-se de angústias e ansiedades. Poucos, muito poucos, são os que envelhecem na advocacia criminal.

Portanto, ver reunido neste plenário um número tão grande de interessados em um Encontro de Advogados Criminais já é, por si só, altamente estimulante, porque se aqui se encontram é, certamente, em razão, pelo menos, da expectativa de haurirem 
informações a respeito de temas e de problemas que se relacionam com o exercício da advocacia criminal. Isto nos consola e nos dá novas esperanças.

Foi pensando em tudo isso que, embora surpreendido com o convite, resolvi enfrentar esta dificuldade e, como advogado criminal, aceitar o desafio de improvisar.

O tema que me foi proposto está centrado na Lei n. ${ }^{\circ}$ 6.416, de 24 de maio de 1977 , principalmente quanto aos motivos e fatos que a originaram. Nesse sentido, acredito, minha exposição poderá contribuir positivamente, pois estive intimamente ligado aos antecedentes e às razões determinantes da sua edição. Posso mesmo dizer, com certa ponta de orgulho, que esse diploma legal resultou de um trabalho iniciado em São Paulo.

No começo do ano de 1971, um grupo de estudiosos passou a preocupar-se sistematicamente com o crescimento da criminalidade e a impossibilidade de recolherem-se aos presídios todos os condenados. Faziam parte desse grupo os Drs. José Luiz Vicente de Azevedo Franceschini, José Rubens Prestes Barra, Francisco Papaterra Limongi Neto, Antonio Carlos Penteado de Moraes, Diwaldo Azevedo Sampaio e este orador. Das demoradas trocas de idéias, baseadas principalmente no texto de uma tese apresentada ao II Congresso Paulista do Ministério Público, pelos Drs. Francisco Papaterra Limongi Neto e Antonio Carlos Penteado de Moraes, resultou uma posição firme dos participantes do grupo, no sentido de que o principal problema do sistema penal residia no fato de existir um grande número de condenações à pena de prisão e total incapacidade de recolhimento dos condenados aos presídios em funcionamento.

Preocupado com o problema, o então Secretário da Justiça, Professor Hely Lopes Meirelles, homem de rara inteligência e aguçada sensibilidade, manteve entendimentos com o grupo, outorgando-lhe o encargo de buscar soluções factíveis. Foi assim que, credenciados pelo Secretário da Justiça de São Paulo, compareceram como seus representantes à reunião dos Secretários da Justiça, realizada em março de 1971 em Nova Friburgo, os Drs. Francisco Papaterra Limongi Neto, Azevedo Franceschini e Diwaldo Azevedo Sampaio. Levavam de São Paulo, então, a primeira colocação a respeito do problema, já muito debatido entre nós, no sentido de que o Código Penal de 1969 não enfrentava corretamente a questão, nem ao menos a equacionava racionalmente, acrescentando que deveriam ser 
promovidas urgentes modificações no Código Penal de 1940, visando à alteração da filosofia penal vigente.

A nova filosofia radicava-se no entendimento de que a pena de prisão deveria ser reservada para os criminosos portadores de periculosidade. Era a idéia que dominara o Congresso realizado pela oNU em 1970 , em Kioto, Japão, para a prevenção do crime e tratamento do delinqüente. Era preciso estabelecer um divisor de águas, para aferir quem deveria ficar preso e quem poderia ficar solto. Admitia-se, como certo, o princípio, hoje muito difundido, de que a prisão fechada não serve para alcançar o duplo objetivo formal a que se propõe: punir e recuperar.

Se se quiser dar um tratamento correto ao problema, não é possível aceitar o binômio, pois seus termos se repelem. Há uma ambigüidade, uma aporia intransponível porque, na realidade, se pretendemos punir, não podemos, no mesmo passo, recuperar.

Essa preocupação, portanto, conduzia à constatação de que a prisão fechada está com os seus dias contados. Os mais recentes trabalhos, dos maiores especialistas no assunto, reconhecem que ainda não existe uma visão clara do futuro, mas há uma convicção autorizada de que a prisão fechada não apenas não recupera, como corrompe. A razão principal disso é que a natureza do sistema - independentemente das pessoas, da falta de recursos humanos, da falta de terapeutas, da falta de recursos materiais - não permite a recuperação.

Ainda recentemente li um trabalho que relata as conclusões a que chegou Norman Carlson, encarregado do "Bureau Federal para as prisões", dos Estados Unidos da América, no sentido de que a prisão fechada não serve para promover a recuperação do sentenciado, pois o erro não está nas pessoas, mas no sistema. Por isso, certamente deverá ser abandonada a idéia de se utilizar a prisão fechada como meio de regeneração do delinqüente.

O sistema de segurança prisional não pode funcionar de outra maneira, mas funcionando como funciona é inadequado para o esforço de recuperação e de ressocialização do condenado. Não se trata de falta de funcionários, de terapêutica ou de recursos materiais. Não. O erro é do sistema, contraditório em si mesmo, pois até nos países onde se gastam generosas verbas, a exemplo da Suécia e dos Estados Unidos da América, é muito alto o índice de reincidência. 
Basta ver que, no sistema de prisão fechada, ao mesmo tempo em que pretendemos dar ao prisioneiro um sentido de dignidade humana, essencial para a sua recuperação, na prática - submetemos a miúdas revistas, a constantes intervenções na sua privacidade, de tal sorte que ele se empobrece totalmente e se envilece, pois é despojado de qualquer sentimento de posse e de auto-respeito. A revista é necessária para a segurança do sistema fechado, mas os seus efeitos são altamente contrários àquele sentido de dignidade que desejamos dar ao homem encarcerado, uma vez que, na verdade, nada há de mais indigno do que um preso que se vê jogado em uma penitenciária, sem direito à privacidade, à propriedade, e cuja individualidade deve estar permanentemente franqueada à intromissão da autoridade.

Mesmo reconhecendo tudo isso, não há como abolir-se a revista das prisões de segurança máxima, o que também acontece com o espírito de iniciativa que se deseja conferir ao interno, mas que é constantemente cerceado por minuciosas regras, legais ou regulamentares, de conduta. Da mesma forma nos comportamos quanto ao sentimento de solidariedade humana, que desejamos despertar no detento, mas que impedimos que se exercite, porque cuidamos, em nome da segurança do presídio, para que os presos não se solidarizem uns com os outros, não se agrupem, e não reivindiquem coletivamente. A associação de prisioneiros dentro de um presídio de segurança máxima é vista como absolutamente indesejável.

Outros exemplos de contradição entre os objetivos da recuperação e os mecanismos próprios do sistema poderiam ser dados, mas basta, por brevidade, o que ficou dito.

Se pretendemos ver a prisão de segurança máxima como instrumental adequado para a dupla finalidade colocada pela lei - punir e recuperar - , estamos completamente enganados, não só pelas razões apontadas, mas também pelo seguinte: o preso, para sobreviver, deve aprender, com a rapidez possível, as regras informais da vida carcerária e assimilar adequadamente os valores predominantes na sociedade prisional.

Ao contrário do que muitos pensam, a prisão não é uma miniatura do mundo livre. A sociedade prisional não é um núcleo reduzido da sociedade livre. $O$ mundo da prisão é típico, estruturado de modo muito específico, regido por regras bem definidas e ostentando sua escala de valores. Trata-se, enfim, de uma comunidade com feições próprias e que difere essencialmente da sociedade livre, até no modo de falar. Exis- 
tem, na hierarquia, categorias sociais diversas, padrões de conduta diferenciados, objetivos definidos. 0 respeito e a admiração são endereçados a valores totalmente diversos dos que predominam na sociedade livre convencional.

Portanto, as regras formais e oficiais existentes no presídio funcionam apenas relativamente às relações entre os presos e a direção do presídio ou seus representantes (guardas, mestres, terapêutas, administradores, etc.), mas não regem as relações entre os presos, na convivência diária do mundo interno da prisão, que se converte em uma verdadeira subcultura. A conseqüência inafastável é esta: o preso aprende que é mais importante assimilar as regras de convivência do grupo do que aprender as normas de comportamento aprovadas pela sociedade livre, à qual ele não pertence. São mais importantes para ele, entre outras, as chamadas "lei do cão" e "lei do silêncio"; mais importantes para ele são os princípios da não delação, da divisão de ganhos, da intransigência e da hostilidade a qualquer tipo de autoridade oficial.

Dois exemplos tornaram bem claro para mim este conceito. $\mathrm{O}$ primeiro deles aconteceu durante uma partida de futebol, jogada entre presos de dois pavilhões da Casa de Detenção, durante um campeonato interno. Num determinado momento, o árbitro apontou uma falta, decisão que não agradou a uma das torcidas. A reação normal se fez sentir, manifestando-se os torcedores contra o árbitro, aos gritos. Porém, o que é muito revelador, ao invés de chamá-lo de "juiz ladrão", apodaram-no de "juiz 'tira' sem-vergonha", numa clara alusão ao valor negativo representado pela polícia. Impressiona esta explosão, num momento emocional, porque trai o condicionamento do valor negativo, expresso não como um gracejo, mas como um sentimento profundo.

O outro exemplo: um delinqüente, multi-reincidente, voltou à Casa de Detenção depois de um curto período de liberdade. Querendo estimulá-lo à recuperação, o Diretor mandou colocá-lo no Pavilhão-2, que é o local onde moram os presos de melhor comportamento e os que colaboram com a administração do presídio. No segundo dia de permanência naquele pavilhão, o referido preso provocou uma briga e surrou um companheiro. Conduzido à presença do Diretor, confessou que assim agira para poder falar com ele, pois desejava a sua transferência para o pavilhão onde estavam recolhidos os presos reincidentes, dizendo que o Diretor bem sabia que ele era bandido e que não aceitava ficar entre os presos "bonzinhos", 
pois isto o diminuía aos olhos dos seus amigos, bandidos como ele. E ameaçou continuar surrando companheiros, todos os dias, até que fosse removido para o "fundão", onde moravam seus amigos.

Estes exemplos tornam bastante compreensível a inversão de valores e o estabelecimento de padrões de conduta inteiramente diversos dos vigentes na sociedade livre. Não é um postulado superficial, mas algo substancial, atuando contra todos os esforços realizados com o objetivo de modificar a personalidade do sentenciado e tornando-os estéreis.

o que ficou dito, porém, não é tudo. Sabemos que é freqüente o caso de um preso que, tendo cumprido uma longa pena e posto em liberdade, meses depois volta a cometer crimes e é de novo recolhido a um presídio. Nunca houve reação da opinião pública ou da imprensa, clamando pela punição do Diretor do presídio que, tendo sob sua custódia esse sentenciado, não o recuperou. Nunca se exigiu a instauração de um inquérito para apurar a responsabilidade desse diretor que, tendo o preso à sua disposição durante cinco ou dez anos, não o regenerou.

Mas, se houver uma fuga, uma fuga apenas, de um presídio de segurança máxima, o mundo desaba. A imprensa clama, temendo pela segurança da sociedade; as autoridades instauram imediatamente um inquérito administrativo para saber de quem foi a culpa; a opinião pública se mostra inquieta e exigente, porque passa a duvidar da segurança do sistema. $\mathrm{Na}$ verdade, é mais importante que um preso não fuja, do que seja recuperado.

A conseqüência disso, também aqui, é desastrosa. Os diretores de presídio passam a dar mais importância à segurança e à disciplina do presídio, do que à tarefa de recuperação dos sentenciados. Se um preso necessitar de um tratamento especial, preconizado pelo psicólogo do presídio, o diretor nega o regime excepcional, porque isso traria reflexos na disciplina da prisão; se um preso praticar uma falta, deve ficar recolhido à cela, ficando privado das aulas ou do trabalho; se dois presos brigarem, ambos devem ser punidos, sem se indagar quem é o culpado, porque assim o exige a tradição de segurança do presídio. E assim por diante. As metas informais da prisão se sobrepóem às metas formais, por força do mecanismo do sistema.

Na mesma linha de raciocínio, há um outro dado que escapa constantemente ao observador desprevenido. Quando 
lidamos com situações perigosas, que podem eclodir em rebelião quando menos se espera, há uma ansiosa expectativa de que o equilíbrio instável não seja quebrado. Isso acontece, precisamente, no sistema de segurança máxima das prisões. O Governador do Estado espera que o Secretário da Justiça cuide bem do problma, evitando acarretar-lhe dores de cabeça. o Secretário da Justiça confia em que o Diretor Geral do Departamento dos Institutos Penais do Estado esteja sempre atento, a fim de impedir que surjam complicações na área das prisões; o Diretor-Geral espera o mesmo dos Diretores dos Institutos isolados; estes desejam que os funcionários administrativos e os terapeutas cuidem atentamente de tudo, afastando possíveis desajustamentos; os funcionários e terapeutas, por sua vez, esperam o mesmo dos guardas de presídio; estes, afinal, mantêm a expectativa de que os presos não venham a dar trabalho com questões disciplinares. Então, é fácil concluir, a chave da tranqüilidade dos presídios está na mão dos presos.

São os presos que, em última análise, ditam as normas da tranqüilidade da prisão, queiramos ou não. Constatei, pessoalmente, esta realidade. Quando iniciei os primeiros movimentos tendentes a introduzir algumas modificações no sistema carcerário, ouvi as advertências dos diretores já integrados no trabalho, ponderando que deveríamos agir com cautela porque os presos poderiam não gostar das novidades e, então, teríamos problemas disciplinares. Lembravam, para argumentar, que em outras oportunidades se tentara isto ou aquilo e que os presos reagiram negativamente, criando situações graves de indisciplina.

Constata-se, assim, que apesar de toda a aparência de força do regime prisional, o sistema não passa de uma frágil estrutura, mantida à custa de transigências e de cuidados, pois os verdadeiros senhores, absolutos e autoritários, são os presos. Ao contrário do que muitos pensam, a disciplina é uma resultante da compensação de forças e do encontro de interesses recíprocos, avençados tacitamente entre os presos e a Administração.

Por tudo o que foi dito é que podemos afirmar que a prisão tem os seus dias contados. Cumpriu já a sua tarefa histórica. Não sabemos ainda o que virá em seu lugar. Mas haverá mudança. Roberto Lyra, no título de um dos seus livros, perguntou: “O que virá depois das prisões?". Mariano Ruiz Funes também tratou do assunto, em livro célebre, desenvolvendo percuciente análise a respeito do que chamou "a crise 
da prisão", assunto por ele versado, aqui mesmo nesta Faculdade, quando proferiu memorável conferência no ano de 1947.

Muitas tentativas foram feitas, e ainda se fazem, procurando compatibilizar as metas incongruentes que se assinalam à prisão fechada. Antes de assumir a Secretaria da Justiça fizemos também uma experiência, que parecia encontrar fundamento em conhecida teoria científica. Acabava de ler alguns trabalhos sobre o "behaviorismo", fulcro do pensamento exposto na obra de Skinner, notável psicólogo norte-americano. Segundo as conclusões a que eu chegara, o método da aproximação sucessiva poderia dar bons resultados quanto à mudança do comportamento de presidiários porque, sem se chegar aos excessos descritos no livro A laranja mecânica, seria possível o recondicionamento da personalidade do delinqüente, através da modificação do seu repertório de respostas, feita de dentro para fora.

Apoiavam minhas conclusões os relatos sobre a modificação de comportamento de soldados norte-americanos, feitos prisioneiros durante a guerra na Coréia, e submetidos a tratamento pelos chineses que dirigiam os campos de recolhimento. Um dos trabalhos que lera mostrava a mudança de comportamento dos soldados, treinados para combater o comunismo, e que, em poucos meses, passavam a escrever artigos e a compor desenhos inteiramente hostis à política norte-americana e bastante simpáticos à ideologia comunista.

O fato tornou-se alarmante quando surgiu na Síria, na India, na Indonésia e no Paquistão, fartamente distribuído através de reproduções, o trabalho de um prisioneiro, que assinava o nome suposto de John Smith, U. S. Army, representando um mapa da Coréia, tendo sobre ele cravadas as unhas sangrentas de uma águia, que aludia claramente à águia americana, pois a sua cabeça era substituída pela cabeça do Presidente Truman, tudo figurando sobre um fundo que representava o símbolo da "Standard Oil".

Segundo o autor do artigo em que esse fato foi relatado, o Pentágono mostrou-se extremamente preocupado, acreditando que os prisioneiros norte-americanos estariam sofrendo processos de lavagem cerebral ou, o que seria pior, dolorosas e insuportáveis torturas chinesas.

Após a troca de prisioneiros em Pamujon, os primeiros repatriados foram interrogados minuciosamente por psiquiatras miltares e civis. Constatou-se, então, que não haviam 
sido torturados ou cruelmente castigados, nem sofreram insuportáveis privações de alimentos ou privações capazes de "quebrar-lhes" o moral. Depois de ouvir os relatos desses prisioneiros, concluiram que haviam sido submetidos às técnicas da psicologia operante, através do sistema de aproximação sucessiva. Este método consiste, basicamente, no seguinte: cada resposta favorável, quanto à mudança de atitude ou de modo de comportar-se, é premiada; cada resposta negativa é punida com uma restrição. Ao cabo de algum tempo o repertório de respostas do sujeito se altera, sem que ele tenha plena consciência da sua participação no processo.

Pareceu-nos, então, que o mesmo método poderia ser aplicado com sucesso nas prisões, obtendo-se, assim, modificações de comportamento dos criminosos. Pedi, na condição de professor universitário, a colaboração de um grupo de jovens integrantes da primeira turma de psicólogos experimentais da Pontifícia Universidade Católica de São Paulo. Interessadas em realizar a experiência, prontificaram-se a prestar colaboração como voluntárias, e iniciaram o trabalho de campo no âmbito da Penitenciária Feminina da Capital.

Passados alguns meses recebi um relatório elaborado pelo grupo, no qual expunham suas conclusões. Segundo as observações feitas, o método não era adequado para a modificação do comportamento essencial do preso. Era possível, sim, mudar aquilo que estivesse relacionado com o ambiente da prisão: se o preso cuspia no chão, não faria mais isso; se tinha o hábito de comer com a mão, deixaria de fazê-lo, e assim por diante. Mas, nenhuma garantia havia de que fosse possível extingüir o comportamento criminoso, pois não havia como fazer aproximações sucessivas concretas da conduta livre, no ambiente da prisão. Em uma palavra, não era possível treinar um homem preso para viver em liberdade. Não existe maneira de criar, na prisão, um ambiente de liberdade, de modo a permitir a experiência autêntica, e não artificial, de liberdade, única forma de se atingir a desejada substituição do repertório de respostas do sujeito.

Esta conclusão, a que chegamos sem custosas pesquisas e sofisticados programas, foi a mesma a que aportaram as autoridades científicas norte-americanas, que empregaram vultosos recursos para empreender a mesma investigação. Somente um projeto, denominado Patuxent, em Maryland, desenvolvido durante 16 anos, custou 40 milhões de dólares, apresentando 
resultado positivo apenas relativamente a 97 dos 2.297 prisioneiros tratados.

Por outro lado, técnicas de intervenção mais direta, como o uso de choques elétricos e drogas, foram condenadas amplamente pelos Tribunais norte-americanos, sobretudo em virtude da ação vigilante da União das Liberdades Civis Americanas (ACLU), sendo certo que o caso Patuxent chegou à Suprema Corte, onde a decisão foi também contrária à poderosa tecnologia comportamental.

Mesmo quando recorreram aos voluntários, os experimentadores não tiveram êxito. Um advogado representou contra esse tipo de tratamento, alegando que na prisão não é possível falar-se em voluntários, pois a simples circunstância de se tratar de um homem preso já lhe retira toda a capacidade de decidir por si. Outras comprovações existiram de que foram empregados métodos de sedução, com promessas de benefícios e de recompensas, para aqueles que se apresentassem como voluntários para as experiências. Por essas razões, os Tribunais rejeitaram as propostas dos controladores do comportamento e vetaram os programas.

Aqui não se chegou a esse ponto. Sem traumas, sem despesas, concluimos que o método não funciona em relação ao objetivo de regenerar criminosos, quando aplicado dentro da prisão. E, é bom que se registre, nossa experiência foi feita de modo original, pois desconhecíamos inteiramente os projetos e programas norte-americanos, muito pouco divulgados entre nós àquela época, ou seja, em 1973.

Afastada essa possibilidade, concentramos nossa atenção no trabalho endereçado à reforma do sistema de penas, iniciado, como dissemos, em 1971. Naquele ano, no mesmo dia em que se realizava a abertura da reunião de Nova Friburgo, proferi a aula magna inicial dos cursos jurídicos, subordinandoa ao tema $A$ Reforma Penal, na qual expus exatamente as mesmas idéias que estavam sendo colocadas pelos nossos representantes em Nova Friburgo. A partir de então, em Congressos, Seminários, palestras, conferências, ciclos de estudos, aulas em todos os Estados da Federação onde estivemos, fizemos a pregação das novas metas, resumindo nossa campanha em alcançar uma significativa alteração no sistema de penas, segundo o postulado: - a prisão fechada deve ser reservada para quem precisa dela.

Custou-nos algum esforço de paciente proselitismo a vitória da idéia. Mas, apesar de algumas oposições e resis- 
tências, o grupo concluía, em 1973, um trabalho sistemático, em forma de anteprojeto de lei, contendo a proposta de substituição de todo o título V do Código Penal de 1969. Esse anteprojeto foi encaminhado ao então Ministro da Justiça, Professor Alfredo Buzaid, que determinou estudos a respeito, estudos que não chegaram a ser concluídos pela sua assessoria.

Foi nessa ocasião que o Senador Franco Montoro tomou conhecimento, acidentalmente, do trabalho e manifestou o desejo de apresentá-lo, primeiro como projeto de lei e posteriormente como emenda substitutiva, quando da discussão do Código Penal de 1969 no Congresso. Também o relator do Projeto, Senador Accioly Filho, mediante gestões do Senador Franco Montoro, interessou-se pela matéria, concordando em vir a São Paulo para debater o assunto com o nosso grupo. Através da ação desses parlamentares, algumas das nossas idéias conseguiram aparecer na lei que reformulou o Código Penal de 1969, editada em fins de dezembro de 1973.

Todavia, como esse Código não entrou em vigor, as medidas ficaram sem efeito. Ao assumir a Secretaria da Justiça do Estado de São Paulo, entendi que deveria propor ao Governador do Estado um engajamento oficial nessa luta, pois um novo sistema de penas muito contribuiria para a solução do problema de superlotação dos presídios. Foi assim que o assunto chegou ao nível de interesse do Governo estadual. Por decreto do mês de abril de 1975, o Governador Paulo Egydio Martins constituia um Grupo de Trabalho, do qual participavam todos os especialistas já referidos, e mais os Professores João Bernardino Gonzaga e Dirceu de Mello.

Em 90 dias, prazo consignado, foi elaborado o anteprojeto de lei, entregue ao Governador em reunião a que compareceram todos os integrantes do Grupo de Trabalho. Determinou-me, então, o Governador, que entregasse pessoalmente o anteprojeto ao Senhor Ministro da Justiça, missão que cumpri no dia 26 de julho de 1975, em audiência que me foi concedida pelo Senhor Ministro Armando Falcão. Basicamente, nossa proposta incluia o seguinte: em primeiro lugar, fossem admitidas outras modalidades de penas, erigindo-se à categoria de penas principais algumas formas de penas acessórias; fossem instituídas expressamente a prisão albergue e a prisão domiciliar; possibilidade de autorização para o preso trabalhar e estudar fora do presídio; concessão do "sursis" à pena de reclusão; redução do prazo para o livramento condicional; prescrição da reinci- 
dência, além de outras medidas com o objetivo de possibilitar tratamento penal diferenciado ao preso sem periculosidade.

Após estudos realizados no Ministério da Justiça, para os quais muito contribuíram os nossos companheiros do Grupo de Trabalho, já agora auxiliados também pelos Drs. Dante Busana e Aldo Almeida Prado de Magalhães, assistentes-técnicos do meu Gabinete, a matéria foi encaminhada ao Congresso Nacional, resultando na edição da Lei n. ${ }^{\circ} 6.416$, de 24 de maio de 1977.

Desde julho de 1975, entretanto, nos dedicávamos com especial interesse a uma campanha para incentivar a implantação de "Casas do Albergado" no Estado de São Paulo, com uma ampla convocação da comunidade, principalmente através das Lojas Maçônicas, Clubes de Serviço, Igrejas Católicà e Evangélicas, União das Sociedades Espíritas, Sociedades de Amigos de Bairros, e outras.

Acredito, sinceramente, na recuperação do delinqüente. Entendo, muito particularmente, que é possível, com os conhecimentos que hoje temos, recuperar $90 \%$ dos sentenciados. $\mathrm{Na}$ verdade, $10 \%$ dos internos são portadores de deficiências que dificilmente reagem aos métodos de tratamento comumente empregados. Em relação a eles seria necessário adotar medidas mais sofisticadas, impossíveis de viabilizar no estágio atual do sistema penitenciário.

Mas, a grande massa é composta de recuperáveis. E o modo mais rápido e eficiente de tratá-los, desde que não estejam em estágio de periculosidade, é colocá-los em contacto com a liberdade. Atualmente nos esforçamos para tornar clara a idéia de que o delinqüente deve ficar recolhido a uma prisão fechada o mínimo possível. Defendemos o entendimento de que o livramento condicional não deve depender de uma quantidade de pena fixa cumprida, mas deve ser concedido logo que haja manifestação favorável de uma Junta Técnica Interdisciplinar.

E sabido que o interno atinge um ponto ideal de recuperação, coincidindo ou não, esse momento, com o prazo legal do cumprimento de determinada quantidade de pena. Hoje perdemos inúmeros casos de recuperação porque a lei fixa um "quantum" de pena para que se conceda a liberdade condicional. Acontece que muitas vezes o sentenciado alcança o ponto ótimo de recuperação e anseia pela oportunidade de voltar ao convívio social, motivado para mudar de vida, mas ainda não cumpriu a metade da pena - se primário - para obter o livramento condicional. Deve continuar preso, sem outra razão além da obrigação de cumprir o tempo de prisão fixado pela lei. A 
partir desse momento, sobre ser inútil, a prisão operará efeitos deletérios e o interno regride.

A adoção de uma nova sistemática, nos termos em que preconizamos, possibilitaria não só aproveitar o momento exato em que a terapia penal atingiu o seu ponto máximo, como também aumentar a rotatividade das vagas nas prisões, aproveitando-as melhor e destinando-as melhor a quem delas realmente necessita. A concessão da liberdade condicional, ou a passagem do sentenciado para a prisão albergue ou para a prisão domiciliar, levando o restante da pena como uma advertência, seria altamente aconselhável, independentemente do tempo da pena ainda a cumprir.

Voltando à Lei n. ${ }^{\circ} 6.416$, podemos afirmar que trouxe reais benefícios, já plenamente sentidos. Nosso indicador é a população carcerária da Casa de Detenção. Verificamos que, após a edição da referida lei, não aumentou mais o número de presos, que crescia à razão de 300 a 500 presos por ano. Ao contrário, a população carcerária decresceu, até a presente data, em números absolutos, de 100 detentos.

Mas, o maior benefício da nova legislação foi, sem dúvida nenhuma, a institucionalização da prisão albergue. $O$ condenado não perigoso, cuja pena seja igual ou inferior a 4 anos, pode gozar desde logo do benefício. Se condenado a mais de 4 e a menos de 8 anos, deverá cumprir um terço da pena, para alcançar o favor legal. Se a condenação for superior a 8 anos, cumprirá dois quintos da pena em outro regime, antes de beneficiar-se do albergamento.

Por que acredito na prisão albergue?

Acredito nela porque está cientificamente provada a sua eficácia. Não se trata, apenas, de um tipo de prisão que favorece economicamente o Estado, embora isso seja também muito importante. Cuida-se, sobretudo, da sua validade para favorecer a reintegração social do sentenciado. A esta conclusão cheguei metodicamente, refletindo muito a respeito do problema da recuperação do delinqüente. Durante dois anos realizamos um ciclo de estudos na Universidade de São Paulo, coordenado pela CODAC, e que reuniu especialistas de vários Institutos. Foi o primeiro trabalho interdisciplinar realizado no gênero, por nossa iniciativa, visando a discutir o problema da responsabilidade do homem, à luz dos conhecimentos atuais de várias disciplinas, tais como a Psicologia, a Filosofia, a Psiquiatria, a Sociologia, a Biologia, a Física e o Direito. 
Das colocações feitas pelos diversos professores que se manifestaram, examinando o problema desde o ângulo da sua especialidade, muitas respostas clarearam as questões discutidas. Para mim, particularmente, uma das mais importantes conclusões foi esta: a personalidade do criminoso é uma estrutura complexa de fatores. Os desdobramentos desta conceituação permitiram-me elaborar uma teoria, valendo-me de uma série de outras observações e juntando diversos ensinamentos. Assim é que conclui, acolhendo a opinião expressa por Norman Carlson, no sentido de que não sabemos muito a respeito das causas do crime e também da maneira de tratar o criminoso, que o crime é um fenômeno que não pode ser examinado segundo as leis da causalidade.

Lembrei-me, então, de um trabalho de Bertrand Russel que induzia à conclusão de que certos fenômenos somente podem ser examinados através de leis estatísticas e não das leis causais. Pareceu-me que o crime se inclui entre esses fenômenos. Na verdade, não é possível afirmar-se quais são as causas do crime. Mas, análises estatísticas permitem a identificação de alguns fatores que conduzem ao crime. Vamos exemplificar: considerando a população carcerária da Casa de Detenção como amostra suficiente, 6.500 presos, verificamos que $90 \%$ dos internos pertencem à classe mais humilde da sociedade, isto é, são pobres. Isto não nos autoriza a afirmar que a pobreza é causa de crime, pois há muitos pobres que não cometem crimes. Mas, se 90\% dos criminosos provêm da classe pobre, podemos concluir, seguramente, que a pobreza é um fator de crime. O mesmo se dirá, exemplificativamente, relativamente ao grau de instrução. Verificamos que $90 \%$ dos presos são analfabetos ou apenas têm instrução primária. Isto não nos autoriza a dizer que a ignorância é causa de crime, pois há muitos ignorantes que não praticam crimes. Todavia, o índice estatístico revela que, se $90 \%$ dos criminosos têm pouca instrução, a ignorância é, seguramente, fator de crime. $\mathrm{E}$, assim por diante, poderíamos isolar outros fatores influentes na criminalidade.

Por outro lado, a confirmar que a pobreza é fator criminógeno relevante, aparece outro dado estatístico: $80 \%$ dos crimes que levaram os sentenciados à Casa de Detenção se constituem de crimes contra o patrimônio, o que permite estabelecer uma relação muito nítida entre pobreza-crime contra $o$ patrimônio. 
Esta análise permitiu que chegássemos a uma outra conclusão, que nos parece também verdadeira, e que é muito importante para a enunciação teórica a que chegamos: a personalidade do delinqüente é uma estrutura complexa de fatores que se entrelaçam e que, num dado momento, eclode num comportamento social desviado.

Muitas personalidades criminosas existem que ainda não deflagraram um ato delituoso, mas estão prontas para fazê-lo assim que a oportunidade se apresente, ou assim que o apelo seja fortemente solicitante.

Ora, se não podemos tratar o criminoso através do exame do comportamento causal, poderemos certamente cuidar de conhecer a sua fatoração criminógena e, em seguida, anular os fatores convergentes. Alguns dos casos de recuperação conhecidos indicam que houve uma mudança dessa fatoração, causando a modificação da personalidade do delinqüente, de dentro para fora.

Entretanto, conduzir metodicamente o processo de anulação dos fatores é algo que dificilmente se consegue no âmbito da prisão fechada. Torna-se muito difícil, senão impossível, decompor a fatoração criminógena e reexperenciá-la no ambiente de repressão, no qual os fatores se tornam praticamente inoperantes, amortecidos. Embora o repertório de respostas do sentenciado se mantenha inalterado, não se oferece ocasião propícia para sua manifestação, por força do ambiente repressivo.

Não obstante, os crimes de homicídio e de lesões corporais acontecem, com certa regularidade, uma vez que, em certas circunstâncias, os fatores criminógenos presentes atuam mesmo no interior da prisão.

Concebemos, então, a teoria seguinte: para que possamos recuperar um delinqüente é preciso desfazer sua fatoração criminógena, decompondo e eliminando os fatores que construíram a estrutura complexa de sua personalidade. E concluímos, também, isto somente pode ser processado no ambiente real de liberdade, através da reexperienciação do quotidiano, ensejando a repetição das ocasiões e das solicitações que ensejaram a formação da personalidade. Somente assim o sujeito pode dar uma resposta opcional nova, formada por ele, assumindo a responsabilidade de decidir. É evidente que esse processo não se viabiliza em uma prisão fechada, pela simples razão de que não podemos simular um ambiente de liberdade 
real dentro do presídio. Embora existam semelhanças formais com a vida livre, na prisão são essencialmente diversas as condições concretas. O trabalho é, geralmente, meramente uma ocupação. 0 local de trabalho fica distante apenas poucos metros das celas. A alimentação é fornecida ao preso sem que este deva realizar qualquer esforço para consegui-la. Enfim, a prisão é repressiva e, contraditoriamente, paternalista.

E impossível, portanto, a reexperenciação do delinqüente encarcerado, quanto ao quotidiano do homem livre, simplesmente porque, por mais que se desejasse ensaiar um ambiente de verdadeira liberdade no presídio, jamais conseguiríamos tal objetivo. Se alguém quiser aprender a nadar, terá que mergulhar um dia na piscina. Por mais que se ensine teoricamente os movimentos da natação, por melhor que seja o instrutor, o aluno não conseguirá aprender a nadar se não concretizar a experiência dentro d'água.

Consoante expressão de um autor, muito citada, tentar treinar um homem preso para viver em liberdade, é o mesmo que treinar um atleta para uma corrida de cinco mil metros fazendo-o permanecer na cama durante os vinte dias que precedem à corrida. Se o sentenciado não fizer a experiência concreta de liberdade, não conseguirá exercitar-se pessoalmente para conseguir a reintegração social adequada.

Por que prestigiamos a "Casa do Albergado"?

As razões são essas que acabamos de enumerar. $\mathrm{E}$ os resultados práticos já obtidos, consoante comprovação feita por uma pesquisa realizada pelo Instituto de Medicina Social e Criminologia de São Paulo, são muito convincentes. Enquanto que o índice de reincidência verificado entre egressos das prisões fechadas é da ordem de $67 \%$, em dois anos de experiência das "Casas do Albergado" o número de reincidentes egressos deste sistema é de apenas 2\%. O índice de abandonos (não fugas, porque os albergados não estão custodiados contra a vontade) é da ordem de $11 \%$, bastante inferior ao número de fugas ocorridas de prisões fechadas. Esta perda é altamente compensadora, à luz do número de delinqüentes recuperados.

Tudo acontece favoravelmente apenas porque os sentenciados vivem a experiência de liberdade, sob o influxo de uma nova motivação (que no início se resume tão somente no interesse de não voltar para a prisão), e sob nova orientação e supervisão dos homens livres que lhes deram a mão. Assim se forma um novo repertório de respostas, autêntico, não 
imposto, sem outras injunções que não aquelas vindas do próprio sujeito.

Vamos dar um exemplo simples: se ao sair do trabalho o albergado recebe o convite para ir a um bar, a fim de ingerir bebidas alcoólicas, coloca-se à sua frente um problema que lhe caberá resolver. Se aceitar o convite, sabe que poderá perder o benefício do albergue. Se recusar, supõe que decairá no conceito dos companheiros que o convidaram. Deve optar livremente. Geralmente tem acontecido que, por temor de perder o benefício e não por virtude, o albergado relutantemente recusa o convite. Esta resposta foi dada por ele, num momento de decisão, assumindo a responsabilidade do que decidiu. Em outras circunstâncias, dificilmente recusaria o convite e poderia embriagar-se, daí decorrendo todas as conseqüências criminógenas. Agora, não.

Se a primeira recusa é difícil, a segunda é mais fácil, a terceira quase não exige esforço e no quarto dia os companheiros já não o convidam mais. Vencida esta batalha, uma nova resposta se instala. Ganhar a guerra dependerá de outras batalhas, nas quais o sujeito estará pessoalmente envolvido. Mas será ele mesmo o lutador interessado. Ao cabo de algum tempo, todos os fatores criminógenos terão sido submetidos a uma revisão e um novo repertório de respostas estará fixado, mudando completamente o comportamento do delinqüente. A recuperação e a reintegração social terão sido conseguidas por ele mesmo.

Estamos apenas no início dessa experiência nova. Mas os resultados são muito animadores, mostrando um caminho largo a ser trilhado. A tarefa não é fácil e depende, em grande parte, do apoio e da compreensão da comunidade. Se a sociedade entender que deve mudar a atitude tradicional, frente ao homem encarcerado, será possível mudar, também, a atitude deste frente à sociedade.

A criminalidade cresce de maneira assustadora. Os índices relacionados mostram que não se trata mais de simples crescimento do número absoluto de crimes, mas de um aumento do número relativo. Se havia uma relação constante entre o número de habitantes e o número de delitos, com crescimento proporcional de ambos, hoje constata-se que o número de crimes cresce mais do que o número de habitantes. Devemos encarar esse fato com seriedade e atenção.

Encontramo-nos em umả encruzilhada muito séria. A humanidade se desumaniza. Percebemos que o avanço tecnoló- 
gico e o aperfeiçoamento dos meios de ingerência na privacidade do homem estão convertendo em realidade a visão profética de Orwell. Tudo aquilo que Alvim Toffler previu em seu livro $O$ choque do futuro está acontecendo com uma rapidez estonteante, e cada vez mais o homem se vê envolvido pelo risco de se robotizar, de se tornar apenas um número em meio a multidões despersonalizadas.

Não sei se nos estamos dando conta efetivamente da responsabilidade. Não sei se estamos conscientizados devidamente da nossa obrigação de atuarmos como agentes transformadores da realidade, ou se, ao contrário, por ignorância, por comodismo ou por covardia, estamos deixando que os acontecimentos nos arrastem inexoravelmente para o extermínio. A tecnologia imperante assume proporções alarmantes e caminha para a substituição do homem pela máquina. O homem deixa de ser um valor em si, para tornar-se, paulatinamente, um valor-meio, uma função da pretendida sociedade do bem-estar.

Freqüentemente assistimos a cenas de descaso pelo homem que não interessa mais ao contexto operacional da técnica e da eficiência. Repete-se, com lamentável assiduidade, o drama exposto por Arthur Miller, na peça $A$ morte do caixeiro viajante, em que o sentimento de abandono, de solidão, de perda do valor pessoal, levou o personagem central à autodestruição.

$\mathrm{E}$ a maior tragédia reside no fato de que a alternativa para afastar essa ameaça parece tão pobre, tão desimportante, tão alienada, que tememos não seja levada a sério. A alternativa é a simplificação da vida, o retorno à humanidade do homem, à poesia, ao verde, ao encantamento do amor. A alternativa é a limpidez dos rios, a abastança das árvores, a pureza do ar, a oxigenação dos mares. A alternativa é não querer um desenvolvimento criminoso, é não desejar um progresso suicida, é querer mais vida, mais comunicação entre os homens, mais solidariedade.

Não sei se seremos capazes, nesse colossal conflito de valores, convencer aqueles que estão conduzindo o processo a prestar mais atenção ao fato de que estamos nos desumanizando. E, neste passo, a responsabilidade do advogado criminal é muito grande, porque da sua atuação decidida, nos campos em que tem participação, depende o encaminhamento da questão. Estamos convencidos de que somente o Direito poderá contribuir decisivamente para a salvação da humanidade, contendo a maré montante da técnica e dos desviados valores, em favor dos bens supremos do homem. 
E, nessa linha, importante papel cabe ao advogado criminal. Não se deixe encantar pelas sereias da tecnologia, que são adoradoras da técnica e da eficiência como fins em si mesmas. Ninguém, melhor do que o advogado criminal, pode ter sensibilidade para perceber o perigo que corremos, porque é ele quem está em contacto permanente com o homem e suas paixões, o homem que também é músculos, sangue, sentidos e espírito. Somente poucos, e entre eles o advogado criminal, podem pressentir o futuro que nos está ameaçando e que já consegue nos assustar.

Senhores, não exerçam a advocacia criminal simplesmente nos autos e nos pretórios. Não se limitem mais à defesa de um constituinte apenas. Subam mais um pouco. Levantem os olhos sobre o mundo e vejam o que está acontecendo à nossa volta, para que amanhã não sejamos acusados de omissão, se o homem, num futuro próximo, solitário e nostálgico de poesia, encontrar-se sentado no meio de um parque forrado com grama plástica, ouvindo cantar um sabiá eletrônico, pousado no galho de uma árvore de cimento armado. 